\title{
ABBREVIATIONS AND CONVENTIONS
}

$\begin{array}{ll}\text { AN } & \text { Archives nationales, Paris } \\ \text { ANOM } & \text { Archives nationales d'outre-mer, Aix-en-Provence } \\ \text { BL } & \text { Central Bodleian Library, Oxford } \\ \text { CS } & \text { Christina Steevens } \\ \text { GWS } & \text { George Warrington Steevens } \\ \text { IMEC } & \text { Institut mémoires de l'édition contemporaine, Paris } \\ \text { Marchand } & \text { Jean-Baptiste Marchand } \\ \text { MECA } & \text { Middle East Centre Archives, St Antony's College, } \\ & \text { Oxford } \\ \text { NLS } & \text { National Library of Scotland, Edinburgh } \\ \text { ODNB } & \text { Oxford Dictionary of National Biography, Oxford } \\ & \text { University Press, 2004 } \\ \text { PCL } & \text { Pembroke College Library, Oxford } \\ \text { PLB } & \text { Private Letter Book } \\ \text { PRO } & \text { Public Record Office, Kew } \\ \text { PSB } & \text { Pierre Savorgnan de Brazza } \\ \text { RHL } & \text { Bodleian Library of Commonwealth and African Studies } \\ & \text { at Rhodes House, Oxford } \\ \text { SAD } & \text { Sudan Archive, Durham University Library, Durham } \\ \text { SG } & \text { Sûreté Générale } \\ \text { WB } & \text { William Blackwood III }\end{array}$

When referred to in a general context, names of military officers are given with the rank that is most commonly used to designate them: for instance, Major (Commandant) Marchand although he became a general in May 1915.

When referred to in the context of French Third Republic politics, Premier or Prime Minister means Président du Conseil.

When making direct quotations, the spelling of local names has been kept intact, even if new conventions have arisen since the production of the work cited.

Unless otherwise stated, titles in English were published in London, and those in French in Paris.

If unspecified, translations from the French were made by the author. 
Berny Sèbe - 9781526103505

Downloaded from manchesterhive.com at $04 / 26 / 2023$ 11:31:27AM via free access 